\title{
Class, Culture and Conflict in the Edwardian Book Inscription: A Multimodal Ethnohistorical Approach
}

Lauren O’ Hagan

\begin{abstract}
This study uses three examples of Edwardian (1901-1914) book inscriptions - a prize inscription, gift inscription and bookplate - to demonstrate how the adoption of an ethnohistorical approach, in which choices of image, colour, typography and materiality are grounded in archival research, can strengthen multimodal analysis. Furthermore, it argues that, while book inscriptions may seem insignificant markers of ownership, they, in fact, act as a material microcosm of many of the social tensions that existed between class groups in early twentieth-century Britain. The analysis reveals that inscriptions were primarily used to objectify their owners' economic means and cultural necessities, and assert themselves in a social space, whether to uphold their rank or keep their distance from other groups. These findings demonstrate the importance of embedding hypotheses concerning the function and form of artefacts in concrete historical documents.
\end{abstract}




\section{Introduction}

In the past thirty years, New Literacy Studies (NLS) has brought attention to the importance of writing as a social practice that is embedded in power relations (e.g. Street, 1984; Barton and Hamilton, 1998). A substantial component of NLS has been its focus on 'ordinary writing', that is, "writing that is typically unseen or ignored and is primarily defined by its status as discardable" (Sinor, 2002:5). When viewed from a social perspective, ordinary writing has the ability to reveal meaningful information about how individuals and social groups organise their lives and make sense of their experiences, and how culture and knowledge is produced and reproduced. Book inscriptions, defined as "ownership marks or annotations present on the front endpapers or title pages of a book" (O'Hagan, 2018:44), are a type of "ordinary writing' that have been largely underexplored due to their appearance as seemingly insignificant markers of ownership. When investigated within the context of the Edwardian era (1901-1914), however, book inscriptions act as a microcosm that reflect, with an unusual intensity, the social conflicts and tensions that existed between class groups in early twentieth-century Britain.

Typically, ordinary writing has been examined using ethnographic or ethnohistorical approaches. These approaches involve living with a community and observing their habits and customs or using archival material to explore said community and its practices, respectively. Ethnohistory as a field focuses on groups of people whose perspectives are underrepresented in official narratives of history backed by national institutions of power (Faudree and Pharao Hansen 2013:240). By emphasising these historically disenfranchised groups, ethnohistory provides an alternative to the dominant perspective, filling in what patriarchal accounts of history have excluded and creating a broader view of social history with a better understanding of the role of 'forgotten people' in social change. While other disciplines may draw upon historical data when attempting to understand the ideologies, cultures and traditions of a particular social practice (i.e., cultural studies, aesthetics), the advantage of ethnohistory is the precedence that its gives to the oppressed, thus making them subjects of formal historical analysis in their own right.

In the context of multimodal studies, despite Kress's (1996) well-established claim that "all texts have always been multimodal" (20), there still remains a heavy focus on digital media and other forms of modern technology (i.e., Ravelli and van Leeuwen, 2017; Benson, 2017; Hiippala, 2018) as opposed to historical texts. Furthermore, many of the studies that use historical data (e.g. O'Toole, 1994; Kress and van Leeuwen, 1996; Granelli and MartinezHinarejos, 2016) seem to have neglected the valuable role that archival documents can play when exploring power dynamics in text creation and production. The introduction of an ethnohistorical approach to multimodality can not only bring about a greater recognition of the importance of grounding choices of image, colour, typography and materiality in archival research, but it can also reframe power relations, particularly favouring the perspective of marginalised groups over the controlling classes. This can, in Samuel's (1988:43) words, "reconstitute the vanished components of the world we have lost."

Despite the fact that the two approaches have their origins in different research domains, ethnohistorical methodologies have many objectives similar to the social-semiotic paradigm within multimodality: both focus on the range of social and cultural resources that are available to a person in a specific context; both draw attention to the motivations that influence a person's selection from these resources; and both accentuate how the social 
effects that these resources may have. What ethnohistory adds, however, is a focus on "real life rather than abstractions, with ordinary people rather than privileged elites, with everyday things rather than sensational events" (Samuel, 1988:42) when carrying out analysis. This means that it allows more flexibility in interpretation, as it acknowledges that texts do not have fixed meanings and are often influenced by the subtleties of power, ideology and cultural distinction. Moreover, when exploring notions of class conflict, ethnohistory incorporates a broad range of theory from sociology, philosophy and cultural studies, which can provide multimodality with working hypotheses, avenues of approach and problem areas that can be refined and tested. Multimodality, on the other hand, can strengthen ethnohistory through the provision of robust methods of analyses with their own established terminology, thus downplaying the possibility of merely anecdotal findings.

In this study, three examples of Edwardian (1901-1914) book inscriptions are used to demonstrate how the co-application of a social semiotic approach to multimodality and ethnohistory can enrich our understanding of historical artefacts, particularly in terms of social class. While the Edwardian era was not the first time that people used book inscriptions, it is perhaps the most interesting period in which to explore this practice, as both increasing literacy and the dramatic decrease in the price of books enabled all classes of society to own them for the first time. This means that these examples of 'ordinary writing' can be explored from the perspectives of all class groups rather than from an upper-class bias. With this in mind, all examples have been collected from second-hand bookshops, given Gillen and Hall's (2010:170) claim that most archives, libraries and personal collections remain heavily biased towards the writing of the elite or distinctive educated individuals.

Supporting multimodal analysis with archival documents, such as censuses, vital certificates and military records enables inscriptions to be made sense of within a larger and broader context of patterned practices and sociopolitical forces. This will allow social semiotic approaches to multimodality to move beyond text-centred analyses, as hypotheses concerning the function and form of artefacts can be derived and explored from concrete historical documents.

Section 2 outlines the benefits of adopting an ethnohistorical approach to multimodality. Then, Section 3 introduces the case study of Edwardian book inscriptions, providing background information on their uses and meanings. In Section 4, the ethnohistorical methodology employed for this study will be described, while Section 5 involves an analysis of three examples from the dataset to demonstrate how this multimodal ethnohistorical framework can be employed. Finally, Section 6 describes the theoretical conclusions of this study.

\section{Towards an Ethnohistorical Approach to Multimodality}

Kress and van Leeuwen's Reading Images: The Grammar of Visual Design (1996) is one of the most widely-received works in multimodality. They conceptualised semiotic resources as interrelated systems of meaning which together constitute and manifest culture (O'Halloran et al. 2016:7). These systems are organised according to three metafunctions: the representational; the interpersonal; and the compositional, each of which roughly corresponds to the three Hallidayan metafunctions (ideational, interpersonal, textual) of Systemic Functional Linguistics. 
While Kress and van Leeuwen's (1996) social semiotic framework is useful for examining the ways in which images communicate meaning, it has received criticism from a range of scholars for its reliance on small datasets that offer limited empirical evidence (Bezemer and Jewitt 2010:194) and its neglect of genre conventions (Bateman 2008:46), sociocultural context (Durie 1997:92) and comparison of modes (Hiippala, 2018:25). Furthermore, due to its text-centredness, it can often result in subjective analyses that give "a post hoc rationalisation of design decisions" (Bateman et al. 2004:67) that may have occurred for other reasons independent of the image itself. When exploring historical artefacts, such as book inscriptions, these issues are particularly relevant, as they risk obscuring the people involved in their production and downplaying the complexities of the Edwardian sociopolitical landscape. Adopting an ethnohistorical approach offers one solution to improve multimodal analysis, as it provides a model that is built on primary evidence and foregrounds social practices as being anchored in the systems and the institutions of the social world (O’Hagan, 2018).

Ethnohistorical methodologies were first used in the 1930s by Fritz Röck to explore African culture through historical artefacts, but they became widely employed in the United States in the 1950 s as a result of the Indian Claims Act of 1946, which sought to give voice to the claims of Native American tribes over land. In the field of linguistics, ethnohistorical approaches were largely pioneered by Dell Hymes (1962) under the umbrella term 'linguistic anthropology' through which he proposed an "ethnography of communication" as an approach towards analysing patterns of language use within speech communities. Despite the fact that many of Hymes' research methods are ethnohistorical in nature, the term has not gained widespread usage amongst linguists. Instead, the method is generally referred to as an "ethnography of documents" (Laurier and Whyte 2001:4), the "anthropology of writing" (Barton and Papen 2010:3), or simply, a "historical approach to ethnography" (Gillen 2013: 491). Within the context of this study, I have chosen to reinstate the anthropological term "ethnohistory", as the definition provided by Faudree and Pharao Hansen (2013) seems to best encompass its aims and research methods:

Ethnohistory - understood as the histories of indigenous people, ethnic minorities and marginalised genders or classes - is a field where attention to language has been employed successfully to construct complex pictures of past sociality. The field differentially integrates methods and theories from a diverse set of disciplines, including social history, historical linguistics, linguistic anthropology and critical theory.

In recent years, there has been a growing interest in semiotic perspectives on ethnography. Katriel (2015:458), for example, has suggested that, ethnographic methodologies must begin to consider interconnections between the temporality, performativity and materiality of communication. However, the most fervent supporters of the co-application of multimodal and ethnographic methodologies remain those working in NLS, such as Pahl and Rowsell (2006). They have argued that, despite often being considered two separate research domains, multimodality and ethnography should be viewed as 
complementary frameworks for investigating the social practices of reading and writing, as both share a view of texts as material and situated, and both use specific research tools to trace social practices and contexts.

This study argues that the co-application of multimodal and ethnohistorical approaches brings further advantages. First, ethnohistory provides multimodality with concrete evidence to support analysis and explore texts within a specific time period. This means that arguments can be rooted in historical concreteness and the context of wider sociopolitical forces, thus ensuring that generalisations are not made until sufficient evidence is provided (Axtell, 1979:4; Rowsell and Chen, 2011:466). Furthermore, as Axtell (1979:5) claims, ethnohistory also has the advantage of being able to move both forwards and backwards in time. This enables cultural patterns to be explored in their original historical context of use, while also informing current and future practices. In the case of social class (the focus of this study), this is especially helpful, given the continued disparities between certain economic and social groups in British society. Another advantage of ethnohistory' is that its focus on the underrepresented allows explorations of power, ideology and cultural distinction to be carried out from a perspective that empowers such groups to claim their history back as their own. In this way, it provides a new panorama of their lives and struggles that is not clouded by bias judgements made by "privileged white people" (Sheehan, 1969:269). Overall, through blending synchronic analysis with diachronic evidence, a multimodal ethnohistorical approach can facilitate the reconstruction of cultural practices, therefore demonstrating that signs do not exist in vacuity, but instead are "shaped by the histories and values of societies and their cultures" (Kress and van Leeuwen, 1996:34).

\section{Edwardian Book Inscriptions as a Case Study}

Book inscriptions have a long history in Britain, dating back to the Medieval age when scribes would freight precious manuscripts with curses to discourage thievery. However, they became popular in the nineteenth century as a result of Victorian commodity culture and Britain's growing obsession with portable property, defined by Plotz (2008) as "everyday culture-bearing objects" (2). By the beginning of the twentieth century, the book occupied a chief position in the households of all classes of society and "hardly a family (...) was without its little shelf of books and its sheaf of current periodicals" (Altick, 1957:5). Book owners used inscriptions as social artefacts loaded with symbolic capital that indicated the amount of prestige that they held (or wished to hold) within Edwardian society (Hammond, 2006:194). These inscriptions ranged from the most rudimentary signature or initials of the owner to an elaborate, custom-designed bookplate or Sunday school prize sticker.

Unlike other ownership marks, book inscriptions should not be confined to the status of a primary impulse or proprietary instinct of claiming an object as one's own; instead, they should be viewed as registers of the cultural and social situation in which the owner and the book met. Book inscriptions act as forms of 'disembodied language' that transform past events into artefacts, make former presences known and produce speech acts that invite readerly projection (Crain, 2016:145). When examined in detail, the power dynamics involved in their creation also comes to the forefront, both from the perspective of the owner and the ideological constructs that shaped the Edwardian world view and system of ideas. These dynamics often disclose information about the social status of the inscriber and the "face" (Goffman, 1959) they wish to present to those who come into contact with the inscription. 
Despite their possibility of revealing vast information about a particular community's literacy, cultural and social practices, book inscriptions remain largely underresearched. Thus far, it is only within the field of provenance studies that they have been explored in any depth, with a particular focus on the ownership inscriptions of wealthy or famous historical figures (e.g. North-Lee, 1979; Pearson, 1998). Furthermore, most literature available on book inscriptions predates the Edwardian era (e.g. Castle, 1892; Hamilton, 1895), as the late nineteenth century was a time in which great public interest first arose in the topic. No prior attempts have been made to investigate the semiotic features of Edwardian book inscriptions, nor to consider their role as indicators of social class. Thus, it is worthwhile exploring the potential of inscriptions as new primary resources to explore class struggles in early twentieth-century Britain.

As a case study, three book inscriptions have been selected for multimodal ethnohistorical analysis. These inscriptions come from a wider dataset of 3,000 Edwardian book inscriptions that were collected from books in the second-hand bookshop, Bookbarn International, in Somerset, England. All of the collected inscriptions were written between 1901 and 1914. Furthermore, all 3,000 inscribers have been investigated using census records and assigned to a class group (underclass, working-class, lower-middle-class, upper-middleclass, upper-class) based on five criteria: occupation, father's occupation, address, family size and number of infant mortalities. This has enabled class-based patterns to be established in terms of inscription types and their semiotic features. The three book inscriptions chosen for analysis in this study have been chosen because they represent the three most commonly occurring inscription types in the dataset (i.e., prize inscription, gift inscription, bookplate). Furthermore, their semiotic features make them prototypical examples of a working-class, lower-middle-class and upper-class Edwardian inscription. Thus, their meanings and functions can be said to be representative of other similar inscription types in the larger dataset.

\section{Ethnohistorical Methodology}

Figure 1 shows an outline of the ethnohistorical methodology that was adopted for this study. As is typical of studies that are rooted in ethnohistory, this methodology incorporates the data collection and analysis processes that were undertaken.

Stage 1 involved the collection of the 3,000 inscriptions, which took place over a ninemonth period in Bookbarn International. All Edwardian book inscriptions, as well as the books in which they were found and any other interesting features, such as booksellers' labels, later inscriptive marks and advertisements, were photographed and field notes were taken on each inscription and the bibliographical details of each book. In Stage 2, all the documentary photographs were uploaded to a computer, edited with Adobe Photoshop and coded with a unique identifying label according to their inscription type. The field notes were then stored digitally on an Access database.

In Stage 3, the genealogical website www.ancestry.com was used to access original historical records for each book owner, including censuses, birth, marriage and death certificates, street directories, military lists and immigration/travel documents. This information helped to locate the inscriptions within a clear context and account for the influence of social conventions and norms on design choices. For the Edwardian period, the 1911 census was particularly useful, as it provides detailed information on the owner's age, gender, address, profession, marital status, siblings, children, place of birth, nationality and 
infirmities. On the basis of this information, each inscriber was assigned to a class group based on the five criteria outlined in the previous section. This assignment was also supported by Charles Booth's 1903 Poverty Maps (https://booth.Ise.ac.uk), which classify streets into seven colours from black to yellow based on class and wealth. The Times, Illustrated London News, The Boys' Own Journal and The Girls' Own Journal were also used to collect institutional information on the companies in which each owner was employed and the social clubs that they attended, while the Archive of British Publishing and Printing at the University of Reading was used to obtain data on the artists, engravers, printers, stationers or booksellers involved in the book production and inscription process.

Stage 4 involved gathering broader information on the sociopolitical context of Edwardian Britain. Using information provided by newspapers on key events that were happening in the world at the same time as the inscription was being produced, for example, may affect the interpretation of the inscription (then and now), as well as the original intentions of the owner. Furthermore, researching the various components of the inscription process (i.e., design, engrave, print etc.) may help to establish the composition of relationships between inscribers, as well as how acts were ordered within the process of inscription as books moved from initial purchase to frequent usage to afterlife.

At this stage, the linguistic form of the inscriptions was also taken into consideration, particularly the type of language, spelling and register used by the owner and what this may reveal about their social status and education. Despite being a written genre, inscriptions can also make use of paralinguistic and prosodic features through choices of typography, colour and picture. Form may also reveal selection rules that govern the use of particular message forms when a choice is made between possible alternatives (i.e., whether the owner uses their full name, a nickname, an honorific etc.). Acknowledging the performative function of inscriptions as forms of cultural capital gives additional meaning to the semiotic and material choices of book owners and suggests that particular design choices may have been influenced more by owners' social goals than strict rules of composition.

Stage 5 involved a preliminary multimodal analysis of each inscription. In all inscriptions, the style and cultural connotation of typeface (van Leeuwen, 2006) was considered, as well as the value and modulation categories of van Leeuwen's (2011) semiotics of colour. The distinctive physical qualities of typeface and its specific intentions, inherent associations and cultural references were often used by owners to reflect particular aspects of their personal identity, while choices of colours were strongly influenced by culturally symbolic meanings or, in the case of some bookplates, by the norms of heraldry. The inscriptions are also investigated in reference to their material features. The semiotics of materiality was developed in my MA dissertation on Edwardian bookplates (O'Hagan, 2015), and is made up of writing implement, printing technique, paper and physical setting. Here, it also encompasses Djonov and van Leeuwen's (2011) separate category of texture, as texture in book inscriptions can be a tangible or metaphorical property (i.e., they could be printed on paper, leather and velvet, or shading and tones could be used to reflect a particular sociocultural connotation). Any images were explored using Kress and van Leeuwen's (1996) representational, interpersonal and compositional metafunctions to determine the use of participants, salience, modality, visual framing and distribution of information value.

The physical copies of the books in which the inscriptions were found were also considered because, by the Edwardian era, publishers were producing books in a range of 
formats, bindings and paper types to appeal to all class groups in society (Lerer, 2012:127). Therefore, a book's format, paper type, typeface, covers and spine, for example, can offer valuable clues into the social status and wealth of the book owner. Furthermore, booksellers' stamps can indicate where books were purchased, while publisher's advertisements and promotional dossiers can highlight a book's intended audiences. This data can provide primary evidence to reduce the potential subjectivity of multimodal analysis.

The final stage combined the previous three stages to carry out a detailed multimodal ethnohistorical analysis of a selection of inscriptions from the dataset. For the present analysis, one prototypical inscription from the three most frequently occurring inscription categories - a prize inscription, gift inscription and bookplate - was chosen for analysis. Prototypicality was based on Rosch's (1975) definition of items in a category that contain the most central features.

\section{INSERT FIGURE 1 HERE Ethnohistorical Methodology}

\section{Book Inscription Analysis}

In this section, three inscriptions will be studied using multimodal ethnohistorical analysis. The analysis brings together an exploration of the semiotic features of each inscription, as well as the sociocultural context and personal backgrounds of all participants involved in their creation.

\subsection{Prize Inscription}

A prize inscription is the name given to any mark in a book which indicates that the book was awarded as a school or Sunday school prize. In Edwardian Britain, awarding books as prizes had become standard practice for most schools, Sunday schools and other institutions. While prize books were typically awarded to a person in recognition of an outstanding achievement or contribution, they also served a secondary function of moral education and they were often used by educational and religious institutions as tools to disseminate approved fiction to working-class children. Bodmer (1999:137) claims that the prize book reinforced the power structure of old and young, while Grenby (2011:174) argues that it advocated the idea that books were to be bestowed on recipients as something that had to be earned. For this reason, I consider prize inscriptions to be a form of 'imposed ownership', a type of ritual communication with a strong control function that was enforced by authority figures.

The prize inscription in Figure 2 was awarded to Katie Cowell, a member of the working-class, by Ballaugh Primitive Methodist Sunday School, and it featured inside the religious novel Broken Barriers by Bessie Marchant. 


\section{INSERT FIGURE 2 HERE Prototypical Prize Inscription (From Broken Barriers, 1889, personal photograph taken by O'Hagan, 2016)}

Primitive Methodism was one of the religious denominations in Edwardian Britain that was most closely associated with the working classes (Calder, 2016:ix). It played an important role in the formative phase of the Trade Union movement in England, and was particularly widespread on the Isle of Man, where Ballaugh is located. At the time of inscription, Cowell was nineteen years old and working as a servant for a Church of England clergyman. The fact that Cowell still attended Sunday school at nineteen is not unusual. As Lacquer (1977:85) notes, although most attendees were children, the age of scholars ranged from five to thirty years old.

Broken Barriers was probably awarded to Cowell to provide her with a suitable model of behaviour. Reynolds (2008:206) claims that, when awarding books to children, institutions often struck a balance between the eradication of working-class culture and the reinforcement of class divisions and social inequality. Analysis of the book's contents confirms this aim, as cleaning and nursing are the two main activities of the book's protagonist, Ruth Maplesden, who claims that all girls' knowledge "must be gained from books" (Marchant, 1889:144).

The prize inscription is written in black fountain pen and plain indelible pencil. The indelible pencil served as a convenient substitute for the fountain pen, as it could be carried on one's person without need for ink or fear of leaks, and provided firm pressure and permanent markings (Dube, 1998). It is likely that the managers of the Sunday school opted for indelible pencil when writing the recipient's name and date so that the inscription did not fade or smudge and would serve as an enduring emblem of Cowell's good behaviour. The fountain pen, on the other hand, was reserved for writing the name of the Sunday school. The differences in writing implement also suggest that the two acts of inscription were carried out at different times. It is possible that the Sunday school name was written in all the copies when they were originally purchased, whereas the prize winners' names were added after they had been selected to receive a prize.

In this example, the type of handwriting is a form of Vere Foster looped cursive. The Vere Foster handwriting style was introduced into schools in the late-nineteenth century. It was deemed a single, general purpose style that blended the needs of elegance and speed, thus making it suitable for both middle- and working-class boys and girls (Smith, 1977:27). This style can be seen clearly in the prize inscription through the letters that are slightly slanted to the right and characterised by rounded ascenders and descenders. The clarity of letterforms in this handwriting would have ensured that the message of the inscription was interpreted clearly by the recipient. The inscriber has also chosen to centre particular elements of the inscription (e.g. 'of the' in Line 2; 'to' in Line 5). This not only makes those words more salient, but it also provides symmetry between the first and third lines and the 
fourth and sixth lines respectively. As Kress and van Leeuwen (1996:93) note, symmetrical composition and equidistant spatial arrangement of different elements connote their equivalent importance. The inscriber has also chosen to underline the date, which marks the end of the reading path and signals the completion of the inscription.

The prize inscription is an example of the continuous conflict between the book as an object of social control and the book as a source of intellectual emancipation. Across the working-class groups in the larger dataset, it is the most common form of inscription. While this suggests that Edwardian institutions were keen to educate the working classes, it is clear that the content of books was chosen by teachers acting in loco parentis with the aim of conveying moral messages as a form of protection against undesirable attitudes and behaviours in working-class children's lives. Reynolds (2008:205) claims that prize books were specifically aimed at working-class boys and girls because they had not yet developed their own coherent world view. Thus, it was easier to curb their awareness of inequality and maintain class divisions.

However, the broader findings of this study suggest that Reynold's generalisation cannot be applied across all members of the working classes. First, the fact that many prize books in the dataset, including that of Cowell's, survive in excellent condition suggests that many owners adapted the intended purpose of the books and drew meaning more from their aesthetic appeal than their actual content. This was particularly important for unskilled working-class children, who may have had very few personal possessions and tangible indicators of achievement in their lifetime. Second, the presence of defaced and damaged prize inscriptions in the dataset suggests that while working-class children may have been the intended objects of control, they developed their own responses by "accepting, rejecting, absorbing, adapting, distorting or countering" (Entwistle, 1990:36-37), rather than blindly accepting middle-class messages. Such defaced inscriptions demonstrate that, even as children, members of the working classes with few prospects of social mobility knew how to carry out acts of symbolic resistance.

\subsection{Gift Inscription}

A gift inscription is an annotation that proclaims a relationship between two (or more) people and is often exchanged on a particular occasion, such as Christmas or a birthday. By giving a book as a present, the gift inscription mediates between the category of an object and a relationship and is an example of what I call 'constrained ownership', given that ownership is granted to the recipient by the giver. When writing a gift inscription, although the book is used as a medium to express social relationships, the inscriber has the ability to shape the medium to their own purposes. This makes the book's status as a commodity become ambiguous and endows it with a fetishlike social power that is unrelated to its true worth (Kopytoff, 1986:83).

Figure 3 shows a gift inscription written by Herbert A. Prince and given to Mrs Ellen Holman. It comes from the 1911 edition of $A$ Journalist in the Holy Land, a travel book about Egypt and Palestine by Arthur E. Copping. 


\section{INSERT FIGURE 3 HERE}

\section{Prototypical Gift Inscription (From A Journalist in Holy Land, 1911, personal photograph taken by O'Hagan, 2016)}

At the time of inscription, Prince was a 44-year-old insurance clerk, living in Sutton, Surrey; Holman was a 52-year-old housewife, also living in Sutton. Holman's son, Lennox, was a work colleague of Prince's [1911 census]. Prince was part of the lower-middle class of Edwardian Britain, while Holman's social background suggests an upper-middle-class woman. Their differences in class may explain Prince's use of atypically ornate calligraphy when writing this otherwise prototypical inscription. Having obtained social mobility through their employment as clerks, the newly emergent lower-middle class was emphatically not working class and felt stridently aware of the fact. Conscious of Holman's own status, Prince may have used calligraphy to index his aspiring education and culture. Prince's choice of book is also interesting, as Egypt and Palestine were popular destinations for middle-class Edwardian tourists. In purchasing this book, Prince was perhaps surreptitiously signalling his desire to be accepted into Holman's social circle. This is supported by the fact that Prince's book cost 6 shillings ${ }^{1}$ [Religious Tract Society Catalogue, 1911] - a considerable amount of money for a clerk whose weekly wage was $£ 3^{2}$.

The first part of the inscription is located on the centre right of the front free endpaper and is written in ornamental gothic script. From an inspection of Prince's handwriting in the 1911 census, it is clear that the handwriting used in the inscription does not resemble his everyday writing practices. Writing in 1906, the craftsman Edward Johnston stated that, "Gothic lettering is one of the most picturesque forms of lettering and therefore of ornament - and besides its ornamental value, there is still in the popular fancy a halo of romance about 'black letter', which may fairly be taken into account" (331). Thus, it is likely that, presenting the book as a gift, Prince deliberately chose this lettering for its aesthetic appeal and positive reflection on himself. Traditional gothic lettering used glossy black for the body text, vermilion for capital letters and gold for decoration. Here, despite the monochrome black ink, Prince has used shading to give the impression of different hues. The first letters of both names and the word 'Christmas' are emboldened, thus accentuating their appearance on the page. The writing style also adheres to other traditional characteristics that gothic script possessed, such as straight vertical orientation and lines produced by small controlled nib movements.

The second part of the inscription, which is separated from the first in a new frame at the bottom left corner of the front free endpaper, indicates a change in writing style. Here, the letters are based on humanist minuscule - a style of script that was invented in secular circles in Italy at the beginning of the fifteenth century. This writing was typically associated with intelligence, the revival of antiquity and beauty (Meiss, 1960:109), and it may have been chosen by Prince to promote an image of himself as someone who is well-educated (and

\footnotetext{
${ }^{1}$ This equates to roughly $£ 33.60$ in modern money.

${ }^{2}$ This equates to roughly $£ 336$ in modern money.
} 
hence, justifiably part of Edwardian middle-class society). This part of the inscription is followed by four three-dotted triangles. Within mathematics, this symbol signifies 'therefore', and may have been employed in this context to signal the physical act of giving the book as a token of gratitude. Alternatively, this symbol can be considered to represent an asterism, which was often used to indicate a break in a text. Although asterisms are used nowadays by typographers as end marks, this was not the case in Edwardian Britain. Therefore, this use of the asterism violates our traditional understanding of its use, as no more text follows. This highlights the importance of considering semiotic choices within their original sociohistorical period of production. Furthermore, the fact that the two parts of the inscription are located in separate frames is also significant, as this separates the act of thanking from the representation of the participants involved in the speech act. This disassociation is further exemplified by the use of the personal pronouns 'his' and 'her' that cannot be linked back to the referents as easily when they appear in a separate frame.

According to Carrier (1990:581), the exchange of gifts is not neutral; rather, it is deeply embedded in cultural meaning. This is particularly apparent in Prince's inscription, whose chief aim is to obtain social respectability over any other factor. In Edwardian Britain, giving a gift was strongly bound up with notions of a "gift-debt" (Mauss, 2011:42) that had to be repaid, thereby forging a mutual interdependence between giver and receiver. Thus, Prince uses gift-giving to establish a personal link between him and Holman, and aspire to a similar social status to his upper-middle-class recipient. It is well-established that the lower-middleclass were far more susceptible to the gift economy of Edwardian Britain (Bailey, 1999) and used gift inscriptions more than any other group as a means of inspiring respect and esteem, while also advancing their interests in upward aspiration. This is a trend that can be seen across the broader dataset.

\subsection{Bookplate}

A bookplate can be defined as a label usually affixed in the front cover of a book, identifying the person or institution to which it belongs. Bookplates emerged from a stage of practical utility to become an object of artistic value, which embodied the individual characteristics of their owners. Traditionally, bookplates were the stronghold of the upper classes of society who commissioned artists to custom design armorial bookplates with heraldic symbols. During the mid-nineteenth century, as the Victorian concern for 'keeping up appearances' grew, middle-class owners began to recognise the potential of bookplates as identity markers. Consequently, stationers and booksellers started to offer bookplate design as an in-house service. By the beginning of the Edwardian era, the application of mass-production newspaper print methods and machinery led to the emergence of cheaper mass-produced bookplates that could be bought in bulk from booksellers. This drastically changed the bookplate market, enabling the lower classes to afford them for the first time. Outraged at the commercialisation of this once bespoke practice, upper-class owners began using particular semiotic and material choices to set themselves apart from others.

This can be clearly seen in the bookplate in Figure 4, an example of 'voluntary ownership', which shows a pictorial library interior design that belonged to the upper-class Edwardian newspaper editor, Ralph D. Blumenfeld. Blumenfeld was American-born but became a naturalised British citizen in 1907 [1911 census]. His bookplate featured in a 1903 travel guide to Oxford. According to the 1903 advertising catalogue of A \& C Black, Oxford was 
the most expensive book they sold at 20 shillings $^{3}$. Its high price was due to the fact that the book was a limited-edition print run with sixty hand-drawn coloured plates by the artist, John Fulleylove.

\section{INSERT FIGURE 4 HERE Prototypical Bookplate (From Oxford, 1903, personal photograph taken by O'Hagan, 2016)}

Blumenfeld's bookplate was printed on copperplate paper and custom-designed by Elizabeth W. Diamond, an avid American bookplate artist and collector in the early twentieth century. Her initials, E.W.D, can be seen in the bottom right-hand corner. A bookplate by Diamond would have cost roughly $£ 20$ and demonstrates the disposable income that Blumenfeld had at this time.

Blumenfeld's bookplate captures a typical Edwardian upper-class lady in her drawing room. Although it is uncertain who the lady in the picture is, images show a similarity to Ralph's wife, Theresa. The picture shows one participant -the lady- who is looking out of the window at a row of thatched cottages. The houses bear a resemblance to Blumenfeld's residence at Hill Farm, Great Eastern in Essex [1911 census], and act as a material sign of his high social status.

The way the lady is presented also provides a lot of information about upper-class life in Edwardian Britain. The bookplate features a wooden lectern, reading chair, double hung windows, stacks of books, flowers and ink and quill - all characteristic features of an Edwardian drawing room (Musson, 2014). These elements act as circumstances that serve as deliberate displays of wealth and high social status. The use of shading gives the furniture the look of solid wood, and perhaps was chosen to reflect the dependable social status of the lady herself. The representation of a wood-like material also grants the border the properties of a physical frame.

The lady's appearance is characteristic of a pre-Raphaelite woman, known for her long curly hair, thick neck, solid jawline and low-necked dress. Here, she is engaged in an act of "offer" (Kress and van Leeuwen, 1996:119): she is not interested in the viewer and, instead, is totally immersed in looking out of the window. This is also characteristic of pre-Raphaelite images in which women are often shown looking away from the viewer. Sawhney (2006) argues that this pose implies the fetishisation of the female as a result of male fantasy. This is supported by Chartier (2002:173), who argues that female reading was often associated with sensual pleasure and secret intimacy. If we consider that the image is of Blumenfeld's wife, the concept of the male viewer as a "privileged voyeur" (Sawhney, 2006) gains additional meaning. However, the fact that her head is angled away from the plane of the viewer suggests that there is no reciprocity between the two entities.

The lady's left-facing position is also noteworthy when compared with the other library interior bookplates in the complete dataset: all of them show the owner facing left. Johnson (2000) claims that direction in portraits was determined by a set of unwritten laws that indicated that a person facing left was looking to past accomplishments, while a person

\footnotetext{
${ }^{3}$ This roughly equates to $£ 112$ in modern money.
} 
facing right was looking to the future. Given that most owners of library interior bookplates were upper-class Edwardians who feared the collapse of a hierarchical society, it is significant that their bookplates may have been used to foreground the 'glorious past' in a bid to hold onto it. The oblique angle of the lady is also meaningful, as according to Tagg (1988), in Edwardian Britain, frontality was considered "a code of social inferiority" (37). Thus, her side positioning serves as an implicit message that could be verbalised as, "I am not part of your world and I do not want to make contact with you. However, feel free to marvel at my wealth and splendour."

The presence of Ralph D. Blumenfeld's name etched on the banderole next to the lady may suggest joint ownership of the book between husband and wife: by means of a verbal representation for Ralph and a visual representation for Teresa, which was not uncommon in upper-class bookplates (Stimpson, 2009:60). This joint ownership is also strengthened by the presence of the Blumenfeld coat of arms resting on the floor in the foreground, the three bees signalling industry, creativity and eloquence (Velde, 2000). The proximity of the German writing below, bedächtig, beständig, bescheiden (thoughtful, steady, humble), encourages the reader to attribute these qualities to the three bees (Zakia, 2007:28) and, by extension, to the family itself.

Thus, it would seem that Blumenfeld uses the bookplate as a symbolic form of domination to perpetuate his high social status and set himself apart from the lower classes who could only obtain status symbolically. For Blumenfeld, the bookplate is an item of cultural capital that enables cultural consumption "to fulfil a social function of legitimating social difference" (Bourdieu, 2010:xxx). This is a pattern that can be observed in custom-designed bookplates throughout the dataset, the majority of which rely on self-portraits, furniture or coats of arms to represent the owner's wealth and high social status. Some are also printed on silk or velvet or use silkscreen, aquatint and woodcut print methods.

\section{Theoretical Conclusions}

In this paper, I have argued that multimodality could benefit from the adoption of an ethnohistorical approach. An ethnohistorical perspective to multimodality has the advantage of moving multimodal, especially social semiotic, analysis beyond a text-centred focus by grounding analysis in archival evidence on particular ideologies, cultures and traditions. The findings gathered from this small-scale case study of Edwardian book inscriptions suggests that carrying out similar analyses on more examples from the larger dataset would offer a valuable extension to current text-centred analyses and provide a greater understanding of artefacts through resources that may not have been considered before. This is particularly important for exploring 'ordinary writing' and capturing the voices of unrepresented people who are often forgotten in history.

The example of Cowell's prize inscription shows how the working-class book often oscillated between an object of social control and a source of intellectual emancipation. While the topic of Cowell's book suggests an imposition of the awarding institution's views on the role of women, it is, nonetheless, significant that Cowell owned a book, given that women's personal ownership had only just been achieved thanks to the 1882 Women's Property Act. Furthermore, it shows an increasing acceptance and will towards women's education and literacy following the 1870 Education Act. 
Prince's gift inscription, on the other hand, shows his middle-class aspirations and highlights how marks of ownership could be used as performative constructs of social mobility. This was achieved through his elaborate choice of typography and colour. However, it is clear that Prince's self-constitution of status meant that he was deprived of any actual profits associated with recognised status.

Blumenfeld's bookplate indicates the full repertoire of semiotic resources available to the Edwardian upper class. This enabled them to commission artists to design custom-made bookplates whose elements were chosen from a range of materials, colours and fonts. Through his bookplate, Blumenfeld transformed into an inventor of the "stylisation of life" (Bourdieu 2010:50), while the classes below became actively involved in this stylisation as they searched for individuality and self-expression.

Bringing ethnohistory and multimodality together has provided a way of uncovering socioculturally induced meanings and functions specific to Edwardian society. For example, choices of writing implements were largely motivated by the fact that black ink was most widely available in shops, as well as long-established social conventions, which dictated that black ink was the most appropriate for writing. Similarly, when considering handwritten inscriptions, it is important to bear in mind that most handwriting can be directly linked to the style that was taught in schools at that time. In cases in which the handwriting style does not match with that which was taught in Victorian or Edwardian schools (i.e., the gift inscription in 5.2), the historical connotations of particular styles must be considered.

Understanding the traditions of Edwardian society has also made it clear how, although book owners had a certain freedom in their choices of image, colour, typography and materiality, as inscriptions began to take on more standardised forms, owners found themselves constrained by the need to adhere to traditional standards of composition. This meant that when creating inscriptions, they kept three factors in mind: an awareness of unspoken historical rules, a recognition of the boundaries of social acceptability, and the constraints and possibilities of the meaning resources available. As a result, all inscriptions were written or pasted on the centre of the front endpaper - the same place that they had been inscribed for more than three hundred years prior. These findings shed light on some particularly interesting sociocultural variables that affect composition and perhaps have not been considered previously.

Combining multimodal tools with archival records has also helped to emphasise the ways in which meaning potentials can shift over time. For example, the types of furnishings displayed in the upper-class bookplate and the use of copperplate paper were strongly bound up with wealth and social status. Nowadays, in a society in which most items are massproduced, we may take these choices for granted and fail to acknowledge their symbolic importance for Edwardians. Furthermore, this approach indicates a need to recognise the subtle rules of Edwardian society when attributing meaning to inscriptions in order to recognise examples of deviation and the potential significance of this nonconformity. An illustrative example is the changing meanings of the asterism in 5.2. In the early twentieth century, it was unusual to end a text with this symbol; therefore, it was likely to have disturbed or upset the reader's expectations. However, in a modern-day context, it is now widely acknowledged as an alternative for the full stop and would not provoke the same responses when seen. 
The methodology used in this study has also enabled a greater understanding of the communicative motions and roles that institutions, such as schools or churches, may have had in influencing and dictating semiotic choices. For example, the prize inscription example demonstrates that many of the semiotic choices were made with an awareness of the fact that the book would be presented at a public prize ceremony attended by parents and children. Consequently, great attention was paid to the choice of book and wording of the inscription to present a positive image of the awarding institution. Creating a good impression of their supposed generosity could bring other benefits, such as increased membership or monetary donations.

Currently, there is much debate about whether multimodality should be viewed as a framework within semiotics or a discipline in its own right. This study has demonstrated that, while a social semiotic approach to multimodality is useful, on its own, it is too text-centric and does not give enough attention to external motivations that may have influenced a text's design. Indeed, van Leeuwen and Jewitt (2000:138) and Bezemer and Jewitt (2010:194) have both argued that multimodality can only ever be one element of an interdisciplinary equation which must also encompass other theories and methodologies.

The ethnohistorical methodology used in the current study provides one such way of enhancing multimodal analysis. It suggests the importance of cross-checking and triangulating multimodal analyses with historical awareness of institutions and social structures. Furthermore, by its focus on 'ordinary writing', it highlights the possibility of revolutionising how multimodal artefacts are understood, particularly in terms of their importance in the lives of marginalised groups as symbolic forms of power. Without an archival investigation into the book owners, nor a detailed exploration of the social norms and conventions of inscriptions, many of these underlying meanings would not have come to light.

Therefore, this study provides support for the notion that multimodality would benefit greatly from the introduction of other research methods to achieve more in-depth analyses that are imbedded within the cultural codes of a particular group. In recent years, there has been a growing awareness of the need for interdisciplinary collaboration between multimodal scholars (i.e., O'Halloran and Smith, 2011; Bateman, Wildfeuer and Hiippala, 2017). Nonetheless, it is clear that there still remains a requirement to develop a growing sense of what other disciplines and approaches can offer in order to take this further. Thus, rather than consider whether multimodality should be its own discipline, continued efforts must be made to anchor it in interdisciplinarity and recognise the benefits of achieving an integrated view that goes beyond the viewpoints offered by any one discipline alone. ${ }^{4}$

\footnotetext{
${ }^{4}$ Please note that an article on the use of a multimodal ethnohistorical approach was published with Social Semiotics in August 2018. However, it involved the analysis of four bookplates.
} 


\section{References}

Altick, R. 1957. The English Common Reader. Chicago: University of Chicago Press.

Axtell, J. 1979. Ethnohistory: An Historian's Viewpoint. Ethnohistory 26(1), pp. 1-13.

Bailey, P. 1999. White Collars, Gray Lives? The Lower Middle Class Revisited. Journal of British Studies, 38. pp. 273-90.

Barton, D. and Hamilton, M. 1998. Situated Literacies. London: Routledge.

Barton, D. and Papen, U. 2010. The Anthropology of Writing. London: Continuum.

Bateman, J. 2008. Multimodality and Genre. New York: Palgrave Macmillan.

Bateman, J., Delin, J. and Henschel, R. 2004. Multimodality and empiricism: preparing for a corpus-based approach to the study of multimodal meaning-making. In: Ventola, E., Cassily, C. and Kaltenbacher, M. eds. Perspectives on Multimodality. Amsterdam: John Benjamins, pp. 65-87.

Bateman, J., Wildfeuer, J. and Hiippala, T. 2017. Multimodality - Foundations, Research and Analysis. Berlin: De Gruyter.

Benson, P. 2017. The Discourse of YouTube. London: Routledge

Bezemer, J. and Jewitt, C. 2010. Multimodal analysis: key issues. In: Litosseliti, L. ed. Research Methods in Linguistics. London: Continuum, pp. 180-197.

Bodmer, G. 1999. Workbooks and Toybooks: The Task and the Gift of a Child's Book. Children's Literature Association Quarterly 24(3), pp. 136-140.

Bourdieu, P. 2010. Distinction: A Social Critique of the Judgement of Taste. London: Routledge.

Calder, S. 2016. The Origins of Primitive Methodism. Woodbridge: Boydell Press.

Carrier, J. 1990. Reconciling Commodities and Personal Relations in Industrial Society. Theory and Society 19, pp. 579-98.

Castle, E. 1892. English Book-plates: an illustrated handbook. London: A \& C Black.

Chartier, R. 2002. The Practical Impact of Writing. In: Finklestein, D. and McCleery, A. eds. The Book History Reader. London: Routledge, pp. 118-142.

Crain, Patricia. 2016. Children in the Margins. In: Crain, P ed. Reading Children: Literacy, Property, and the Dilemmas of Childhood in Nineteenth-Century America. Philadelphia: University of Pennsylvania Press. pp. 109-143.

Djonov, E. and van Leeuwen, T. 2011. The semiotics of texture: from tactile to visual. Written Communication 10(4), pp. 541-564. 
Dube, L. 1998. The Copying Pencil: Composition, History, and Conservation Implications. The Book and Paper Group Annual [online] 17, Washington DC: The American Institute for Conservation Available at https://cool.conservation-us.org/coolaic/sg/bpg/annual/v17/bp17 -05.html [Accessed: 14 August 2018].

Durie, M. 1997. Reading images: the grammar of visual design, by Gunther Kress and Theo van Leeuwen: review. English in Australia 119, pp. 92.

Entwistle, D. 1990. Children's Reward Books in Non-Conformist Sunday Schools, 1870-1914: Occurrence, Nature and Purpose. Unpublished PhD thesis, University of Lancaster.

Faudree, P. and Pharao Hansen, M. 2013. Language, society and history: Towards a unified approach? In: Enfield, N.J., Kockelman, P. and Sidnell, J. eds. Cambridge Handbook of Linguistic Anthropology. Cambridge: Cambridge University Press, pp. 227-249.

Gillen, J. 2013. Writing Edwardian Postcards. Journal of Sociolinguistics 17(4), pp. 488-521.

Gillen, J. and Hall, N. 2010. Edwardian postcards: illuminating ordinary writing. In: Barton, D. and Papen, U. eds. The Anthropology of Writing. London: Continuum, pp. 169-189.

Goffman, E. 1959. The Presentation of Self in Everyday Life. New York: Anchor Books.

Granelli, E. and Martinez-Hinarejos, C. 2016. A Multimodal Crowdsourcing Framework for Transcribing Historical Handwritten Documents. Proceedings of the 2016 ACM Symposium on Document Engineering. Vienna, Austria, September 13-16, 2016, pp. 157-163.

Grenby, M. 2011. The Child Reader, 1700-1840. Cambridge: Cambridge University Press. Hamilton, W. 1895. Dated Book-Plates. London: A \& C Black.

Hammond, M. 2006. Reading, Publishing and the Formation of Literary Taste in England, 1880-1914. Aldershot: Ashgate Publishing Company.

Hiippala, T. 2018. The Structure of Multimodal Documents. London: Routledge.

Hymes, D. 1962. The Ethnography of Speaking. In: Gladwin, T. and Sturtevant, W.C. eds. Anthropology and Human Behavior. Washington DC: Anthropology Society of Washington, pp. 13-53.

Johnson, D. 2000. Left vs. Right, The E-Sylum [online] 3(15) Available at http://www.coinbooks.org/esylum_v03n15a05.html [Accessed: 14 August 2018].

Johnston, E. 1906. Writing and Illuminating and Lettering. New York: Dover Publications.

Katriel, T. 2015. Expanding Ethnography of Communication Research. Communication Theory 25, pp. 454-459.

Kopytoff, I. 1986. The Cultural Biography of Things: Commoditization as Process. In: Appadurai, A. ed. The Social Life of Things. Cambridge: Cambridge University Press, pp. 64-95.

Kress, G. 1996. Representational resources and the production of subjectivity: Questions for the theoretical development of critical discourse analysis in a multicultural society. In: Caldas- 
Coulthard, C. and Coulthard, M. eds. Text and Practices: Readings in Critical Discourse Analysis. London: Routledge, pp. 15-31.

Kress, G. and van Leeuwen, T. 1996. Reading Images - The Grammar of Visual Design. London: Routledge.

Lacquer, T. 1977. Religion and Respectability: Sunday Schools and Working-Class Culture 1780-1850. New Haven: Yale University Press.

Laurier, E. and Whyte, A. 2001. 'I saw you': Searching for lost love via practices of reading, writing and responding. Sociological Research Online 6(1), pp. 1-10.

Lerer, S. 2012. Devotion and Defacement: Reading Children's Marginalia. Representations 118(2), pp. 126-153.

Marchant, B. 1889. Broken Barriers. London: Joseph Toulson.

Mauss, M. 2011. The Gift: forms and functions of exchange in archaic societies. Eastford: Martino Fine Books.

Meiss, M. 1960. Towards a more comprehensive Renaissance palaeography. The Art Bulletin 42(2), pp. 97-112.

Musson. J. 2014. The History of the Country House Drawing Room [online] Available at http://www.countrylife.co.uk/articles/history-country-house-drawing-room-63348

[Accessed: 14 August 2018].

North-Lee, B. 1979. British Bookplates - A Pictorial History. London: David and Charles.

O'Hagan, L. 2015. Multimodality in Edwardian Bookplates: The Rediscovery of a Lost Art. Unpublished MA thesis, Cardiff University.

O'Hagan, L. 2018. Class, Culture and Conflict in the Edwardian Book Inscription: A Multimodal Ethnohistorical Approach, Unpublished PhD thesis, Cardiff University.

O'Hagan, L. 2018. Towards a multimodal ethnohistorical approach: a case study of bookplates. Social Semiotics. [online] Available at https://www.tandfonline.com/doi/f ull/10.1080/10350330.2018.1497646 [Accessed: 14 August 2018].

O'Halloran, K. and Smith, B, 2011. Multimodality Studies - Exploring Issues and Domains. London: Routledge.

O'Halloran, K., Tan, S., Wignell, P., Bateman, J., Duc-Son, P., Grossman, M. and Vande Moere, A. 2016. Interpreting text and image relations in violent extremist discourse: A mixed methods approach for big data analytics. Terrorism and Political Violence [online] Available at https://www.tandfonline.com/doi/full/10.1080/09546553.2016.1233871 [Accessed: 14 August 2018].

O’Toole, M. 1994. The Language of Displayed Art. London: Routledge.

Pahl, K. and Rowsell, J. 2006. Travel Notes from the New Literacy Studies, Clevedon: Multilingual Matters.

Pearson, D. 1998. Provenance Research in Book History. London: The British Library. 
Plotz, J. 2008. Portable Property. Princeton: Princeton University Press.

Ravelli, L. and van Leeuwen, T. 2018. Modality in the Digital Age. Visual Communication. 17(3). pp. 277-297.

Reynolds, K. 2008. Rewarding Reads? Giving, Receiving and Resisting Evangelical Reward and Prize Books. In: Briggs, J., Butts, D., and Grenby, M. eds. Popular Children's Literature in Britain. Aldershot: Ashgate, pp. 189-209.

Rosch, E. 1975. Cognitive reference points. Cognitive Psychology 7(4), pp. 532-547.

Rowsell, J. and Chen, L. 2011. English Studies through a New Literacy Studies-Multimodal Lens. In: Street, B. and Leung, C. eds. The Routledge Companion to English Studies. London: Routledge, pp. 464-475.

Samuel, R. 1988. 'What is Social History?'. In: Gardner, J. What is History Today...?. London: MacMillan. pp. 42-57.

Sawhney, P. 2006. The Pre-Raphaelite Body [online] Available at http://www.victoria nweb.org/painting/ prb/sawhney.html [Accessed: 18 March 2018].

Sheehan, B. 1969. Indian-White Relations in Early America. William and Mary Quarterly 26, pp. 267-286.

Sinor, J. 2002. The Extraordinary Work of Ordinary Writing. lowa City: University of lowa Press. Smith, P. 1977. Developing Handwriting. London: Macmillan.

Stimpson, F. 2009. The library at Wallington: National Trust Libraries 3. Book Collector 23(3), pp. 45-71.

Street, B. 1984. Literacy in Theory and Practice. Cambridge: Cambridge University Press.

Tagg, J. 1988. The Burden of Representation: Essays on Photographies and Histories. London: Palgrave Macmillan.

van Leeuwen, T. 2006. Towards a Semiotic of Typography. Information Design Journal 14(1), pp. 139-155.

Van Leeuwen, T. 2011. The Language of Colour: An Introduction. London: Routledge.

van Leeuwen, T and Jewitt, C. 2000. Handbook of Visual Analysis. London: SAGE Publications. Velde, F. 2000. Heraldic Atlas [online] Available at http://www.heraldica.org/topics/ glossary/atlas.htm [Accessed: 14 August 2018].

Zakia, R. 2007. Perception and Imaging. Waltham: Focal Press.

\section{Biography}

Lauren O' Hagan recently completed a PhD in Language and Communication within the School of English, Communication and Philosophy at Cardiff University. Her thesis was entitled 'Class, Culture and Conflict in the Edwardian Book Inscription'. It involved an interdisciplinary 
approach, that blended theory from Multimodality, Ethnography and Book History, to explore social class in Edwardian society through a dataset of 3,000 inscriptions present in books circulated between 1901-1914 in Britain. Lauren currently works as a translator and EFL tutor. 